\title{
Spotted Cats and the Amazon Skin Trade
}

\section{Nigel J. H. Smith}

In Brazil the trade in spotted cat skins - mainly jaguar and ocelot - built up in the early 1960s and provoked the Government in 1967 to outlaw all commercial exploitation of wildlife. The author estimates that this cut the annual kill from 15,000 jaguars and 80,000 ocelots to about half, which he thinks both populations can stand without becoming endangered. Moreover, the programme of massive development and settlement on the forest margins along the new Transamazon highway has run into difficulties, and forest destruction has so far been much less than was expected.

The Amazon basin, covering over five million sq $\mathrm{km}$ and embracing the world's largest continuous tropical rain forest, provides one of the last remaining havens for most of the Neotropical cats in demand for the fur trade. But it is neither virgin nor immune to the hand of man. In the past, world demand for forest products - drugs, spices, rubber - has attracted waves of immigrants, many of whom, after the usual market collapse, stayed to farm the land by slashing and burning the forest. This report describes the recent boom-and-bust cycle of the cat-skin trade and assesses its impact on the cultural and biotic landscape.

Jaguar Panthera onca, the largest Neotropical cat weighing up to 100 kilos, is the richest prize for the fur hunters. Skins of onca pintada, as the jaguar is known in Brazil, that I have measured (from nose to base of tail) vary from 1.3 to 1.6 metres, and an undamaged pelt of a fully-grown healthy animal

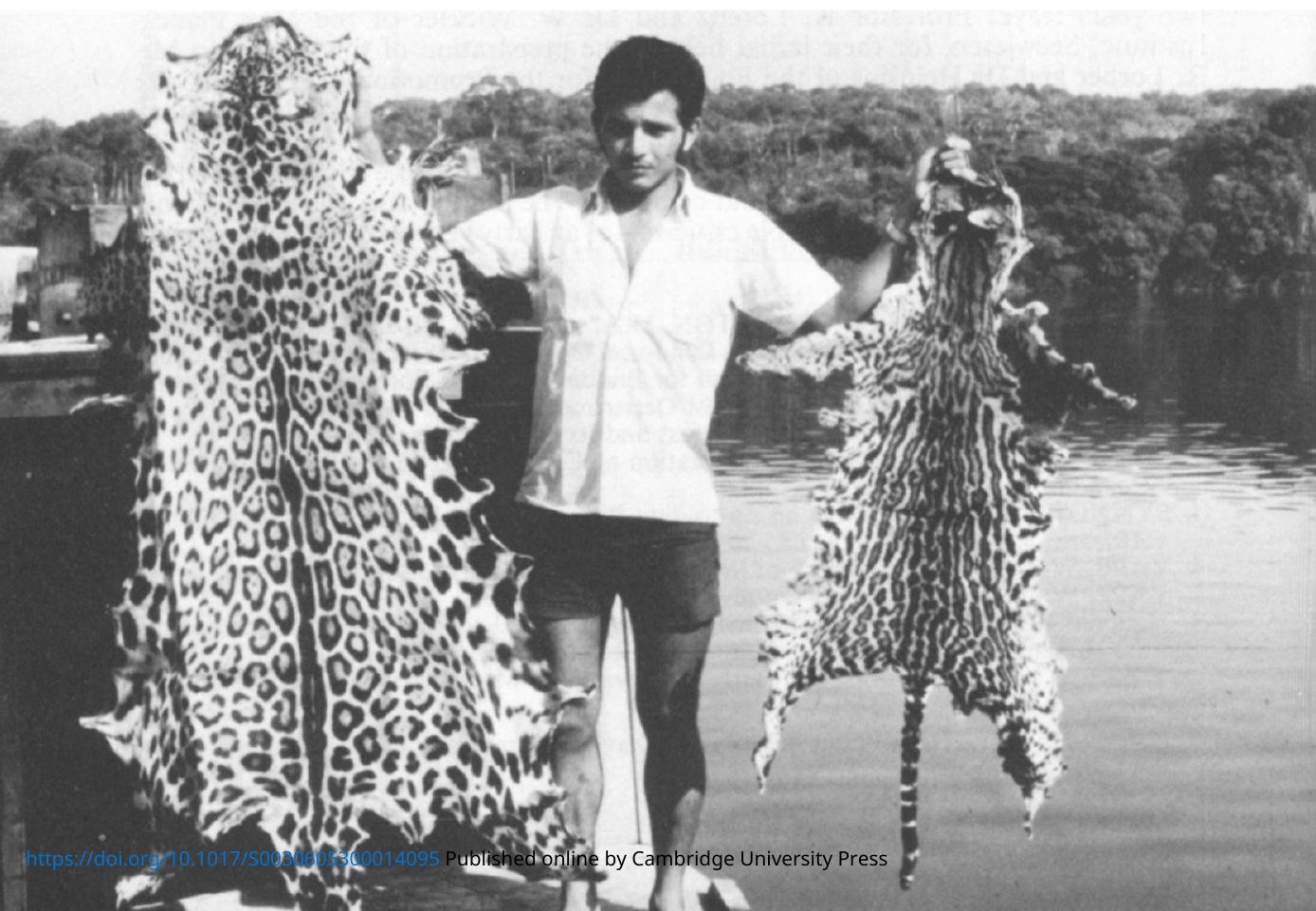




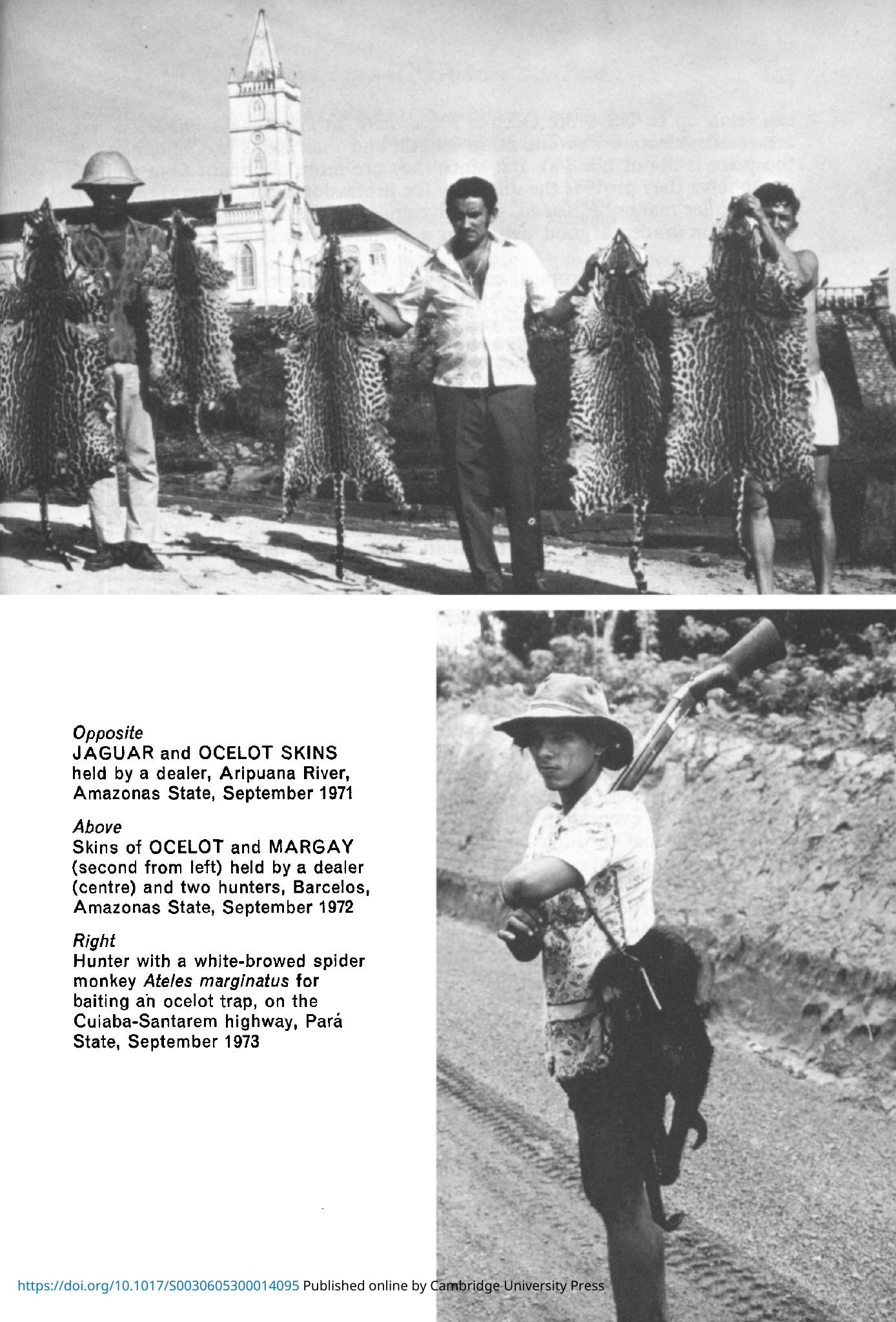


can fetch up to US $\$ 130$. Ocelots $F$. pardalis, in Portuguese maracajá-açu, are smaller, from 0.7 to one $\mathrm{m}$. in length, and their skins less valuable; the top price is about US $\$ 40$, but since they are more abundant than jaguars in the selva they provide the mainstay for professional cat hunters (gateiros). The smaller margay $F$. wiedii, generally under $0.5 \mathrm{~m}$. long, is less prominent in the skin trade; a good pelt from a mature maracajá-peludo may fetch US $\$ 10$.

The unspotted Neotropical cats have little commercial value. The background rings on black jaguar, or panther, pelts detract from the jet-black look, but they are hunted for meat. Puma $F$. concolor is also eaten, salted sundried steaks being especially savoury; skins of both these large cats are used to make baskets and seat covers. Jaguarundi $F$. yagouarundi, the smallest jungle cat, is not highly regarded either for its meat or its ashy-red fur.

\section{The Trade}

The Brazilian spotted-cat skin trade began to accelerate in the $1960 \mathrm{s.}^{2}$ Before that, pressure was only locally heavy, the result of habitat destruction around urban centres and along agricultural frontiers. But in the 1960s middlemen provided supplies to thousands of gateiros and sent them fanning out into the selva, until the Brazilian government felt compelled to act, and on January 3rd, 1967, passed law 5.197 outlawing the commercial exploitation of all wildlife. Stunned skin dealers complained vociferously that they were caught with 'huge' stocks and faced financial ruin; they were allowed until April 30th, 1971 to liquidate these bloated stocks, after which no wild animal skins could be legally traded.

By employing grossly exaggerated inventories, however, dealers were able to continue purchasing skins from their network of travelling buyers in the aviador system, and pressure on the spotted cats actually increased (Tables 1-4). Pelts swapped hands, quite openly in the interior (Figs 1, 2), more covertly in the larger trading centres such as Belém and Manaus. Illegally obtained skins were finding ready markets in the US and Western Europe (Table 5), and, even after the April 1971 deadline, cat skins were still being exported by boat through Leticia on the Colombian Amazon, and by light aircraft via the Guyanas. Regular scheduled air cargo carriers were also employed - in April 1972, for example, Pan Am officials at New York's Kennedy airport discovered a crate from Brazil en route to Canada, labelled 'leathers', containing hundreds of spotted cat skins. (See Oryx, XII, 1).

Controlling the illegal export of wild animal skins in Brazil is the task of the under-staffed Instituto Brasileiro de Desenvolvimento Florestal (IBDF), who have not nearly enough guardas to patrol all highways, rivers and airports effectively. Moreover, few guards would risk confronting the political barons and powerful commercial leaders who often figure prominently in the illicit skin trade. The dealers' political influence is not to be underestimated. Recently they won another grace period to liberate stocks of spotted cat and other wild animal skins, including giant otter Pteronura brasiliensis, peccary Tayassu spp., and red brocket deer Mazama americana, when IBDF and Banco do Brasil authorised an eight-month liquidation period from January to August 1974. It seems unlikely that these stocks had accumulated from kills prior to 1967 or even 1971 .

Of course it is quite unrealistic to expect a developing nation such as 
Table 1 Jaguar and Ocelot Skin Exports from Marabá, Pará

$\begin{array}{lccccrcccc}\text { Species } & 1966 & \text { Destination } & 1967 & \text { Destination } & 1968 & \text { Destination } & 1969 & \text { Destination } \\ \text { Jaguar } & 27 & \text { Belém } & 21 & \text { Belém } & 53 & \text { Belém } & 19 & \text { Belém } \\ & & & & & 101 & \text { Ceará } & 57 & \text { Ceará } \\ & & & & & 5 & \begin{array}{c}\text { Goias } \\ \text { Maranhão }\end{array} & \text { São Paulo } \\ \text { Total } & 27 & & 21 & & 164 & & 85 & \\ \text { Ocelot } & 434 & \text { Belém } & 100 & \text { Belém } & 749 & \text { Belém } & 1008 & \text { Belém } \\ & & & 272 & \text { Ceará } & 534 & \text { Ceará } & 547 & \text { Ceará } \\ \text { Total } & 434 & & 372 & & 1283 & & 230 & \text { São Paulo } \\ & & & & & 1785 & \end{array}$

Source: Inst. Brasileiro de Geografia e Estatistica, Marabá.

Note: These figures are a small fraction of the actual trade.

Table 2

Jaguar and Ocelot Skin Exports from Altamira, Pará

$\begin{array}{lrrrrrrr}\text { Species } & 1964 & 1965 & 1966 & 1967 & 1968 & 1969 & 1970 \\ \text { Jaguar } & 15 & 68 & 18 & 93 & 146 & 459 & 316 \\ \text { Ocelot } & 429 & 1314 & 225 & 3095 & 2414 & 4485 & 5801\end{array}$

Source: Agencia de Estatistica do Municipio de Altamira.

Note: The figures represent perhaps $50 \%$ of real trade. All skins destined for Belém.

Table 3

$\begin{array}{ccr}\text { Jaguar and Ocelot Skin Exports from Itait } \\ \text { Species } & 1967 & 1969 \\ \text { Jaguar } & 19 & 136 \\ \text { Ocelot } & 51 & 4013\end{array}$

Source: 1967-IDESP (Social and Economic Development Institute for the State of Pará). 1969-Secretaria da Fazenda: Dept. de Exatoria do Interior.

Table 4

US Imports of Jaguar and Ocelot Skins 1968-69

\begin{tabular}{lrrrr} 
& \multicolumn{2}{c}{ Jaguar } & \multicolumn{2}{c}{ Ocelot } \\
Source & 1968 & 1969 & 1968 & 1969 \\
Brazil & 8,093 & 6,389 & 60,499 & 81,226 \\
Colombia & 881 & 883 & 28,132 & 23,823 \\
Peru & 157 & 689 & 3,170 & 2,938 \\
Bolivia & 1,190 & 51 & 16,172 & 513 \\
Paraguay & 1,797 & 585 & 4,532 & 3,293 \\
Mexico & 593 & 452 & 5,603 & 6,186 \\
Other & 805 & 782 & 10,858 & 15,090 \\
Total & 13,516 & 9,831 & 128,966 & 133,069
\end{tabular}

Source: US Dept of Interior, Office of Endangered Species.

Table 5 Jaguar Skin Exports from Brazil 1969

$\begin{array}{lrr}\text { Destination } & \text { Kilos } & \text { Value US \$ } \\ \text { USA } & 30,085 & 2,875,224 \\ \text { W. Germany } & 8,762 & 979,674 \\ \text { UK } & 8,615 & 772,674 \\ \text { Switzerland } & 707 & 86,033 \\ \text { France } & 480 & 63,655 \\ \text { Canada } & 169 & 24,250 \\ \text { Austria } & 119 & 19,950 \\ \text { All Countries } & 48,937 & 4,821,521\end{array}$

Source: Ministerio da Fazenda, Rio. Comercio exterior do Brasil, 1970. 


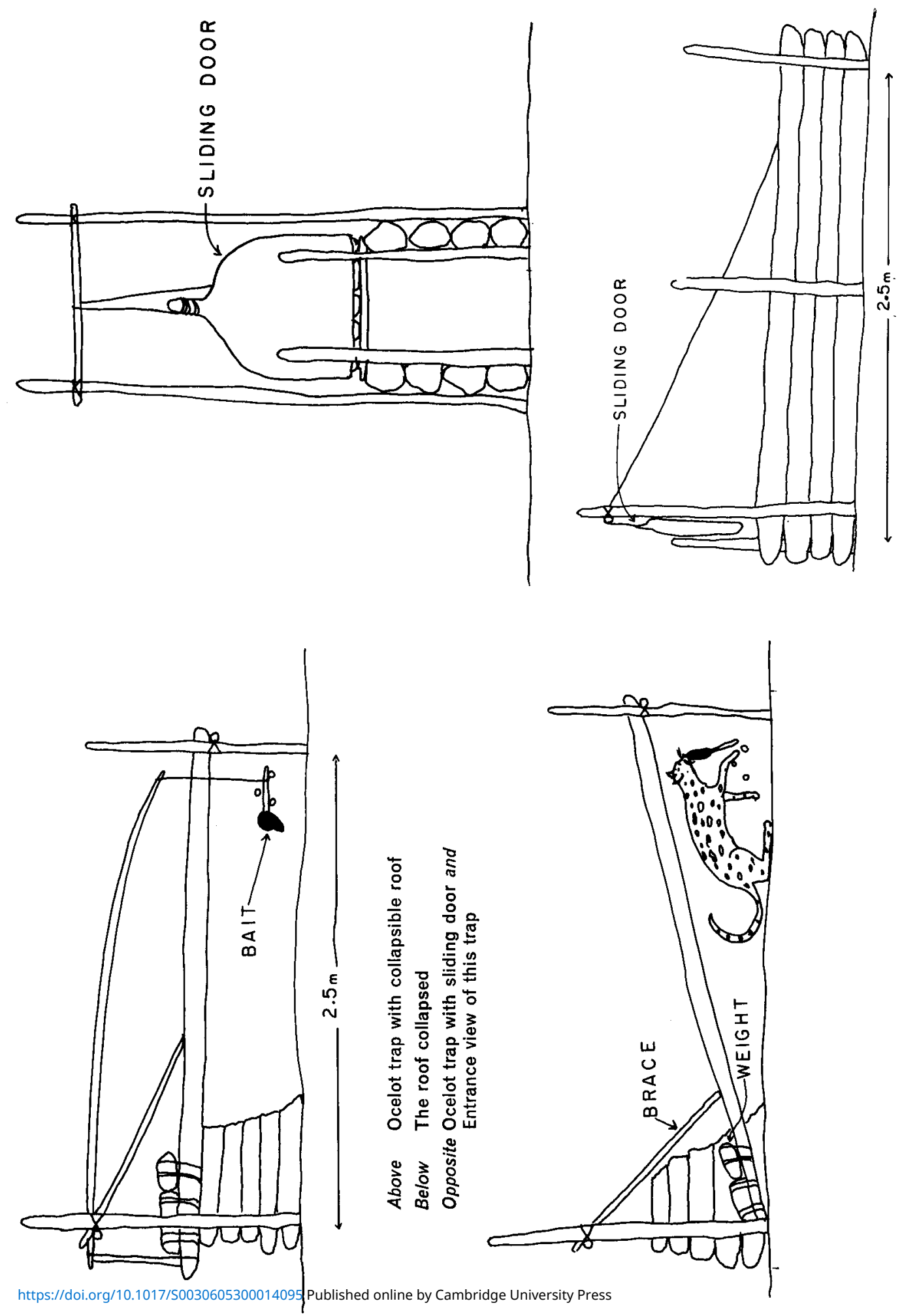


Table 6 Prices paid to hunters for top quality skins, Brazilian Amazon, 1971-73

$\begin{array}{ccc}\text { Year } & \text { Jaguar } & \text { Ocelot } \\ 1971 & 80 & 15 \\ 1972 & 130 & 40 \\ 1973 & 100 & 30\end{array}$

Note: Value in US \$.

Source: Author's field survey.

Brazil to control the skin trade in a 5-million-sq-km rain forest with approximately $8000 \mathrm{~km}$ of frontiers with countries which do not all prohibit trade in wild animal skins (e.g. Surinam). Outright banning of all trade in spotted-cat skins is not only impossible but undesirable, for wild animal pelts significantly supplement the income of many peasants in the Amazon as well as providing a livelihood for thousands of gateiros. The important point is to control the killing so that the resource is renewable. Undoubtedly responsibility for controlling the skin trade should rest with importing countries. The US has prohibited the import of spotted cat skins, and buyers in Canada and Europe should moderate their purchases, if only in their own interests, by means of a commonly agreed quota.

\section{Hunting Methods}

Gateiros seek mostly jaguar and ocelot because their pelts fetch the highest prices-Table 6. A prime jaguar pelt can bring in the equivalent of six months' wages. Lured by such incentives, many caboclos (peasants) left subsistence agriculture and ranches to become gateiros.

Cat hunters usually work in teams of 2-4 for companionship and as protection against attack by Indians. They stock up with shotguns (mostly 16 and 20 bore), shells, coffee, sugar, salt and manioc flour from their patrâa (dealer), buying on credit with the understanding that the skins must be sold to him. After covering their debts, increased by inflation prices, the hunters receive any outstanding money. They penetrate the interior forest by rowing up headwater streams at the end of the rainy season, usually May, when water is high. Some walk into the interfluvial forest, whereas others are flown to remote airstrips by their patrão. After a few months, a small plane returns to pick up any skins.

When they find ocelot tracks hunters construct a series of traps, made of local wood, such as the easily-worked açai palm Euterpe oleracea, and bound together with vines. Monkey meat is preferred bait, although birds such as curassows, guans and tinamous are said also to be favoured ocelot food. In one model, the bait is attached to a stick wedged between horizontal poles. When an ocelot tugs at the meat, dislodging the stick, a noose slips off and releases a sprung pole which supports the weighted end of the roof (Figures $4 a, b)$. The roof then crashes down trapping the prey. To prevent the cat from pushing the roof up and escaping a brace is installed. In a more complex model, a tug on the bait releases a sliding door (Figures 5a,b). Jaguars rarely enter the traps.

A hundred or more traps may be set at intervals of approximately 500 metres along several watercourses, and periodically checked. This enables the hunters to cover hundreds of square kilometres during the six-month hunting 
season in the drier months. Trapping enables them to kill the cat without damaging the pelt, usually done by shooting it in the head with a pistol or strangling it with a nylon noose.

\section{Jaguar Lures}

Jaguars can be lured by using an instrument designed to imitate the panting groan of this nocturnal cat, made from a tube of hollow wood, such as bamboo, covered at one end with stretched hide. Horse-tail or other tough hair is passed through a small hole punched in the covering; one end is tied and pulled through the hollow core. To coax a jaguar, the hunter wets his finger and repeatedly pulls on the hair, while his companion quietly rows up and down a stream, listening. If a jaguar comes to the water's edge to investigate, they spotlight it and shoot. Another method is to groan into a hollow gourd; the deep resonating sound can be heard by humans for several hundred metres and by jaguars probably even further. Ocelots are attracted with whistles, made from the metal casing of a flashlight battery, that imitate the piercing cry of an agouti (Dasyprocta spp.). The metal is bent into a wedge shape with a small hole punched through the upper surface. The hunter puts the lower surface on his lower lip and blows over the pierced upper surface. With all calling methods the knack is to resist the temptation of calling too frequently. Furthermore, if the hunter varies the quality of the sound the cats become suspicious and retreat.

If a gateiro is sure a jaguar prowls the vicinity, he may set a nocturnal trap. He drags the bloody carcass of a peccary or a brocket deer along the ground to leave a scent trail, fastens it to the base of a tree, and then waits with flashlight and shot gun in his own hammock slung some three metres above ground.

Subsistence hunters, rubber tappers and other gatherers of forest products also occasionally encounter a cat. If they have dogs, these will usually tree the cat which thus presents an easy target. Since IBDF guards stepped up their harassment of the gateiros, pelts obtained by these casual hunters have accounted for much of the current trade.

The success of professional cat hunters depends on locale and skill. This is the record of one hunter in Pará state:

\begin{tabular}{lccc}
\multicolumn{1}{c}{ Year } & $\mathbf{1 9 6 9}$ & $\mathbf{1 9 7 0}$ & $\mathbf{1 9 7 1}$ \\
\multicolumn{1}{c}{ Location: } & Rio Itacaiunas & Rio Anapu & Rio Penetecal \\
Traps: & 40 & None & 150 \\
Jaguars: & 2 & 1 & 1 \\
Panthers: & - & -3 & 1 \\
Ocelots: & 13 & - & 39 \\
Pumas: & - & - & 2
\end{tabular}

In 1970 he did not trap, preferring to wait at night by bait tied to a tree (espera method), but the following year he returned to the trap method, and, with the aid of a companion, increased his yield considerably.

Gateiros preserve spotted cat skins by rubbing them in salt before stretching them over a framework of sticks to dry by the campfire for several days, after which they are liberally sprinkled with DDT or other pesticide to discourage insects, especially ants, and rolled in bundles. The dealers sort the skins into two or three classes according to size and shot damage before export. 


\section{Impact of Hunting on Populations}

Although the aboriginal population in the Amazon may have been dense, especially along the floodplains, hunting pressure on the cats was light. Some cultures killed jaguars to provide ceremonial wear, but for the most part jaguars were feared and respected. Only with the coming of Europeans, and the opening of international markets, were the spotted cats hunted extensively, and what began as a trickle of skins in the early 1960s rapidly increased to a flood by the end with the development of improved tanning techniques. I estimate that as many as 15,000 jaguars and 80,000 ocelots were being shot out of the Brazilian Amazon every year in the late 1960s. The current take is probably half, thanks to both national and international restrictions. But the crucial questions are: did the increased slaughter rate cause a permanent decrease in the cat populations? And is the current offtake a bearable cropping rate?

Little is known of the habits of jaguar or ocelot in the wild, but, on the basis of hunting data collected from two settlement communities (agrovilas) along the Transamazon highway, ${ }^{5}$ I estimate that a jaguar needs $100 \mathrm{sq} \mathrm{km}$ of forest to hunt its prey, principally peccary and brocket deer. In the course of a year, hunters operating within $100 \mathrm{sq} \mathrm{km}$ of their agrovilas (distances are measured by lot demarcations) removed one jaguar from each community hunting area. In one of the study agrovilas, a panther, two pumas and three ocelots were also taken in the 100-sq-km hunting area within a year. Brocket deer and peccary (the two most abundant large herbivores) and tapir Tapirus terrestris account for most of the meat taken for each community. The hunters say a jaguar is incapable of tackling a fully-grown tapir, which can weigh up to 200 kilos, has a thick hide, runs fast and can defend itself aggressively in water with forefeet and teeth; hunter's dogs have been severely wounded in this manner.

In riverine habitats the carrying capacity for jaguars is higher because there is also aquatic prey, such as capybara Hydrochoerus hydrochaeris, caimans, turtles and fish. But this optimum habitat has been largely pre-empted by man, particularly along 'white water', muddy rivers such as the Amazon, Madeira and Purus. These are constantly fed with silt from headwater erosion in the Andes, and deposit sediment on the floodplains downstream, where the resulting alluvial soils are more fertile and flatter, and thus more suitable for agriculture, than the upland, generally undulating, terra firme soils. Furthermore, the numerous floodplain lakes of these nutrient-rich river systems provide abundant fishing especially in the dry season. By contrast, 'black water' rivers, such as the Rio Negro, drain predominantly nutrient-poor podzols and carry little sediment. Lacking a fertile floodplain and abundant fish, they are notorious for their hunger (rios de fome), and sparsely settled, with the riverine vegetation and fauna still largely intact; consequently, they may still provide optimum habitat for jaguars.

However, most of the Amazon basin is unflooded interfluvial forest or terra firme. If we assume an average of one jaguar per $100 \mathrm{sq} \mathrm{km}$, then there would be 50,000 dispersed across the 5 -million-sq-km forest. Assuming that 15,000 breeding pairs each produce two cubs every other year, the annual recruitment would be roughly 15,000 young. Allowing a loss of one-third the first year, production of yearling jaguars would be about 10,000 . However, I think it unlikely there are 15,000 breeding pairs left after centuries of hunting, intense in the last decade. Furthermore, gateiros may have so thinned stocks in some areas that suitable mates do not encounter one another. 
It therefore seems likely that the estimated 10-15,000 annual jaguar take in the late 1960s and early 1970 s was excessive and would have seriously depleted the population if it had not been checked. However, it does not appear to have thinned numbers permanently. Along one $25-\mathrm{km}$ stretch of the Transamazon highway, starting from $65-\mathrm{km}$ west of Altamira in Pará state, five jaguars were sighted in a year in 1973/4: one was shot in the forest, another killed a mule along a side road, a pair reportedly watched a farmer and his wife harvest maize, while the fifth was seen crossing the highway at night.

The current estimated take of $5000-7000$ jaguars is probably bearable. The jaguar, at least, appears to be more resilient than expected, and it is only at the extremes of its vast range, ${ }^{3}$ from Argentina to Mexico, and in denselysettled El Salvador, ${ }^{1}$ that populations appear to be endangered.

The population density of ocelots is much higher. My studies of hunting on the Transamazon ${ }^{5}$ indicate that for every jaguar taken from $100 \mathrm{sq} \mathrm{km}$ of forest three ocelots were removed. Traps catch mostly ocelots. Total exports from rain-forest environments in 1964-70 (Tables 1, 2, 3) indicate a kill ratio of 29 ocelots to 1 jaguar. (Table 4 covers both forest and savanna environments). Ocelot-jaguar ratios vary from 10:1 for all of Brazil, to 12:1 for Peru and 29:1 for Colombia.

In the Amazon the actual population density of ocelots is probably in the region of 1 per $10 \mathrm{sq} \mathrm{km}$. Neither the increased hunting pressure in the late sixties, when around 80,000 a year were killed, nor the current take of approximately $30-40,000$, appear to have seriously impaired their breeding capacity. Ocelots are chicken raiders along the entire Transamazon in spite of gateiro traps and angry retaliation by farmers, and they appear to adapt to secondary growth plant communities on the periphery of man-made clearings, preying, as margays also do, on small game, such as agoutis Dasyprocta spp., pacas Cuniculus paca, nine-banded armadillos Dasypus novemcinctus, and tinamous, which thrive in successional vegetation.

\section{Future Pressures}

The Amazon basin is being criss-crossed by a series of pioneer roads such as the Transamazon and the new 5000-km Perimetral Norte, but these 'national integration' highways are unlikely to threaten the status of the wild cats seriously for several decades. Even the much toted $3000-\mathrm{km}$ Transamazon highway, which promised to settle hundreds of thousands by 1975 , has made little significant impact on the rain forest ecosystem. ERTS satellite imagery shows the three-year-old highway as a mere hairline fracture across the vast canopy. Although a $20 \mathrm{~km}$ wide strip has been set aside by the government for farming, only about one kilometre of corridor has been effectively claimed from the forest. Poor soils and the selection of unsuitable crops have slowed down the colonisation rate so that the current highway population at 50,000 is barely growing.

Cattle raising, spurred by the incentives that allow companies to invest 50 per cent of their income tax in such projects, is a far more serious threat to the rain forest ecosystem. Along the Transamazon alone 3.7 million ha of forest are slated for artificial pasture. Recently Volkswagen and some Arab concerns have expressed interest in opening up ranches, and 'petrodollar power' could make potentially serious changes in the Amazon forest eco- 
system in a very short time. But the 'grass rush' into the Amazon could be averted without diminishing beef production, if existing pastures were improved by more intensive management systems. ${ }^{6}$

The sheer size of the Amazon forest, some 500 million ha, seems likely to buffer development depredations for several decades. Nevertheless, the offtake of the spotted cats should not exceed current levels, and responsibility for control should rest with importing countries, especially the buyers themselves, to avoid depleting a renewable resource.

\section{References}

1. DAUGHERTY, H. 1972. The Impact of Man on the Zoogeography of El Salvador. Biol. Cons., Vol. 4, No. 4, p. 276.

2. DOUGHTY, R. and MYERS, N. 1971. Notes on the Amazon Wildlife Trade. Biol. Cons. 3, 4: 293-297.

3. KOFORD, C. 1974. Latin American Cats: Economic Values and Future Prospects. Third International Symposium on the Ecology, Behavior, and Convervation of the World's Cats. Seattle, Washington.

4. IUCN 1973. Bulletin, Vol. 4, No. 3, p. 11.

5. SMITH, N. Transamazon Highway: a cultural-ecological analysis of settlement in the lowland tropics. Ph.D. dissertation, Department of Geography, University of California, Berkeley (in preparation).

6. STERNBERG, H. 1973. Development and Conservation. Erdkunde, Band 27, Lfg. 4, p. 257.

\section{Javan Rhinos in Laos?}

Evidence suggesting that the one-horned Javan rhino Rhinoceros sondaicus may survive in southern Laos was discovered by Harvey Neese in the course of a fivemonth visit to Cambodia and Laos last year to search for kouprey on behalf of the New York Zoological Society. (As reported in the last Oryx he found that they did.) Hitherto the Javan rhino was thought to survive only in the Indonesian Udjung Kulon reserve, on Java, and possibly in the Gunung Leuser in Sumatra. However, he was able to report three incidents believed to have involved rhinos, and ten instances of 'rhino evidence' between 1955 and 1974 - animals seen, tracks seen, or horn produced. The most impressive is the account of an elephant round-up in June 1974. Thirteen trained elephants, each carrying two men, were rounding up a group of five wild elephants when they realised that among the five were two adult rhinos. One man yelled 'Het! het!' (rhino) and both rhinos and three of the elephants escaped.

\section{What a Tapir Needs}

In a brief paper in the Malayan Nature Journal (28, 2, December 1974) Lord Medway describes the highly selective browsing of a tapir Tapirus indicus on either side of a forest track. Figs were the most popular browse; succulent gingers and bananas were abundant but rejected. The author points out the conservation implications: first, a much larger range is needed to support a tapir than any similar-sized but less selective herbivore; second, its preferred food plants inevitably bring it into contact with man - and tapirs are in fact frequently encountered in logged or regenerating areas and poor plantations, which is dangerous for them and gives a misleading impression of abundance; third, the tapir is unable itself to maintain the environment it likes. If a reserve should be needed to protect the tapir, a large area of virgin forest deficient in these particular food plants would be little good. Active management to provide these plants would be necessary.

Hubert Hendrichs's report on the status of the tiger Panthera tigris in the Sunderbans, Bay of Bengal, based on his field work in 1971, (see Oryx xi, 4) is published in Säugetierkundliche Mitteilungen 23. 3. 